\title{
PENCAPAIAN HASIL BELAJAR TEORI KEJURUAN DITINJAU DARI PERSEPSI MAHASISWA PADA PEMBELAJARAN ONLINE
}

\author{
Sukardi ${ }^{1}$, Muhammad Hudan Rahmat ${ }^{2}$ \\ ${ }^{1,2}$ Program Studi Pendidikan Teknik Mesin, Fakultas Keguruan dan Ilmu Pendidikan, Universitas Palangka Raya \\ Email: sukardioto@gmail.com
}

\begin{abstract}
One of the effort to overcome the ineffectiveness of face-to-face learning is to extend the interaction outside the classroom framework. In this case, advances in information technology can be utilized. The use of technology that functions like classroom face-to-face is through online learning. This study aims to find out: (1) student perceptions of online learning (a Moodle platform); and (2) the effect of student perceptions of online learning on the learning outcomes of Vocational Theory course. The research object was 117 students. The data analysis being used were descriptive statistics and Kendall's tau. The results of the study indicate that online learning is an excellent medium to complement the face-to-face learning. The contribution of perception of learning outcomes found in this study is only $1.70 \%$. It can be said that $98.0 \%$ of learning outcomes are determined by other factors.
\end{abstract}

Keywords: learning media, moodle, online learning, face to face, descriptive statistics, kendall

\begin{abstract}
ABSTRAK
Upaya yang dapat dilakukan untuk mengatasi masalah ketidak efektifan pembelajaran tatap muka adalah dengan membuat ekstensi berinteraksi di luar kelas. Dalam hal ini, kemajuan teknologi informasi dapat dimanfaatkan. Penggunaan teknologi informasi yang memiliki fungsi seperti layaknya tatap muka dalam kelas tersedia melalui pembelajaran online. Penelitian ini bertujuan untuk mengetahui: (1) persepsi mahasiswa terhadap pembelajaran online (plat form Moodle); dan (2) pengaruh persepsi mahasiswa pada pembelajaran online terhadap hasil belajar Teori Kejuruan. Objek penelitian berjumlah 117 orang mahasiswa. Teknik analisis data menggunakan statistik deskriptif dan Kendall's tau. Hasil penelitian menunjukkan bahwa pembelajaran online merupakan media yang sangat baik untuk melengkapi pembelajaran tatap muka. Besarnya nilai kontribusi persepsi terhadap hasil belajar yang ditemukan dalam penelitian ini hanya $1,70 \%$, atau $98,30 \%$ hasil belajar ditentukan oleh faktor lain.
\end{abstract}

Kata kunci: media pembelajaran, moodle, pembelajaran daring.

\section{PENDAHULUAN}

Saat ini, kecenderungan pemanfaatan media online sebagai media pembelajaran semakin meningkat dalam dunia pendidikan kita khususnya di perguruan tinggi. Ditinjau dari metode interaksi, pembelajaran secara online berbeda dengan pembelajaran tatap muka. Pada metode tatap muka, biasanya mahasiswa dan dosen bertemu muka secara langsung, sedangkan pembelajaran secara online keduanya tidak bertemu langsung di dalam kelas, tetapi bertemu secara maya di dalam kelas virtual. Kecanggihan teknologi informasi dapat memfasilitasi pembelajaran selakyaknya metode tatap muka, meskipun mahasiswa dan dosen tidak bertemu secara langsung dalam kelas.

Masalah yang biasanya ditemui dalam dunia pendidikan khususnya di Perguruan Tinggi mengharuskan dosen memanfaatkan media online sebagai solusinya. Misalnya masalah satuan kredit semester (SKS) yang selama ini dinilai masih kurang maksimal dalam proses pembelajaran.

Besarnya SKS mata kuliah dimaknai sebagai waktu yang dibutuhkan mahasiswa untuk dapat menguasai kompetensi yang telah dirumuskan dalam suatu mata kuliah. Satu SKS 
setara dengan 170 menit kegiatan belajar. Untuk mata kuliah non-praktikum terdiri dari 50 menit tatap muka (Tm), 60 menit belajar terstruktur (Bt), dan 60 menit belajar mandiri (Bm) (SN-Dikti, 2015). Permasalahan yang sering dijumpai saat ini adalah dosen hanya memberikan kegiatan $\mathrm{Tm}$, atau dosen telah memberikan kegiatan $\mathrm{Tm}$ dan kegiatan $\mathrm{Bt}$ namun tidak terkontrol. Selain itu dosen telah memberikan kegiatan $\mathrm{Tm}$ dan kegiatan $\mathrm{Bt}$ dengan baik, namun mahasiswa tidak memanfaatkan kegiatan $\mathrm{Bm}$. Endrotomo (2016), menyatakan bahwa kondisi perkuliahan sekarang ini memang masih banyak yang belum melaksanakan SKS dengan benar, masih ada yang hanya menyelenggarakan kuliah $\mathrm{Tm}$ dan ujian. Jika kondisinya demikian, maka beban studi yang diterima mahasiswa hanya $1 / 3$ dari jumlah SKS yang telah ditetapkan.

Upaya yang dapat dilakukan untuk mengatasi masalah tersebut adalah dengan membuat ekstensi untuk berinteraksi di luar kelas. Dalam hal ini, kemajuan teknologi informasi dapat dimanfaatkan. Penggunaan fungsi pembelajaran sebagaimana layaknya di ruang kelas tersedia dalam pembelajaran berbasis online.

Direktorat

Pembelajaran

dan

Kemahasiswaan, Ristekdikti telah merintis pembelajaran daring/ Sistem Pembelajaran Daring (SPADA) Indonesia, dengan terus meningkatkan akses terhadap mata kuliah bermutu dari dosen-dosen Perguruan Tinggi Negeri dan Swasta di seluruh Indonesia. Dengan demikian pembelajaran online akan banyak digunakan pada Perguruan Tinggi di Indonesia, baik dalam bentuk full online maupun blanded-learning. Untuk menunjang Visi Pendidikan Tinggi tersebut, kajian tentang pencapaian hasil belajar ditinjau dari persepsi terhadap lingkungan pembelajaran online masih sangat diperlukan. Hal ini mengingat bahwa pembelajaran online memiliki keterbatasan. Dalam beberapa studi, pembelajaran full online dianggap kurang menguntungkan (Tayebinik dan Puteh, 2013). Hal tersebut dikarenakan pembelajaran full online tidak memungkinkan untuk tatap muka secara langsung di dalam kelas, sehingga seluruh kebutuhan pembelajaran tidak terakomodasi (Tuncay dkk, 2011). Ini menjelaskan bahwa perlu adanya kajian seperti apakah pembelajaran online yang efektif. Tujuan penelitian ini adalah untuk mengkaji : (1) persepsi mahasiswa terhadap lingkungan pembelajaran online (Moodle), dan (2) pengaruh persepsi mahasiswa pada lingkungan pembelajaran online terhadap pencapaian hasil belajar Teori Kejuruan.

\section{METODE}

Penelitian ini menggunakan metode expost-facto, yaitu menganalisis pengaruh variabel amatan tanpa memberi perlakuan terhadap variabel yang ada. Teknik analisis data menggunakan statistik deskriptif dan Kendall's tau. Teknik analisis data tersebut digunakan untuk mendeskripsikan persepsi mahasiswa pada lingkungan pembelajaran online dan dampaknya terhadap pencapaian hasil belajar Teori Kejuruan. Data persepsi diperoleh dari teknik angket, sedangkan data hasil belajar diperoleh dari nilai akhir mata kuliah. Subjek yang digunakan dalam penelitian ini berjumlah 117 orang mahasiswa.

\section{HASIL DAN PEMBAHASAN}

Persepsi Mahasiswa pada Pembelajaran Online Moodle. Deskripsi persepsi mahasiswa pada pembelajaran online, disajikan dalam Tabel 1. berdasarkan Tabel 1, dapat dijelaskan bahwa 87,50\% $(\mathrm{S}=63,80 ; \mathrm{SS}=23,70)$ mahasiswa memberikan tanggapan positif (setuju dan sangat setuju) terhadap pernyataan bahwa lingkungan belajar online seperti sebuah komunitas dimana saya (mahasiswa) dapat berkomunikasi dengan dosen \& mahasiswa. $87,50 \%$ tanggapan positif dari mahasiswa bukan tanpa alasan. Dalam pembelajaran online mahasiswa dituntut untuk kolaborasi. Rancangan tugas mengharuskan mahasiswa untuk bertanya, berdiskusi, serta berbagi referensi secara online. Peran dosen adalah 
fasilitator jalannya proses diskusi online. Dengan demikian dapat disimpulkan bahwa penggunaan fungsi diskusi seperti layaknya di ruang kelas tatap muka tersedia di dalam pembelajaran berbasis online.

Tabel 1. Persepsi Mahasiswa pada Pembelajaran Online Moodle

\begin{tabular}{|c|c|c|c|c|c|c|}
\hline No & Pernyataan & SS (\%) & $\mathrm{S}(\%)$ & $\mathrm{N}(\%)$ & $\mathrm{KS}(\%)$ & TS (\%) \\
\hline 1 & $\begin{array}{l}\text { Lingkungan belajar online seperti } \\
\text { sebuah komunitas dimana saya dapat } \\
\text { berkomunikasi dengan dosen dan } \\
\text { mahasiswa lainnya }\end{array}$ & 23,70 & 63,80 & 4,30 & 7,80 & 0,40 \\
\hline 2 & $\begin{array}{l}\text { Aktivitas seperti : forum, chat, } \\
\text { assignments, dan quiz membantu } \\
\text { saya dalam mendalami materi }\end{array}$ & 22,40 & 60,80 & 3,00 & 12,50 & 1,30 \\
\hline 3 & $\begin{array}{l}\text { Menggunakan pembelajaran online } \\
\text { membantu saya dalam } \\
\text { mengembangkan kemadirian belajar }\end{array}$ & 25,00 & 66,80 & 2,20 & 5,60 & 0,40 \\
\hline 4 & $\begin{array}{l}\text { Melalui aktivitas diskusi secara } \\
\text { online, saya dapat menyampaikan } \\
\text { pendapat dengan lebih baik } \\
\text { dibandingkan ketika diskusi tatap } \\
\text { muka di kelas }\end{array}$ & 19,80 & 49,60 & 7,30 & 17,70 & 5,60 \\
\hline 5 & $\begin{array}{l}\text { Tugas-tugas yang saya kirimkan } \\
\text { secara online mendapatkan koreksi } \\
\text { dari dosen dengan cepat, sehingga } \\
\text { saya dapat merevisi tugas }\end{array}$ & 35,80 & 56,90 & 1,30 & 5,20 & 0,90 \\
\hline 6 & $\begin{array}{l}\text { Pembelajaran online adalah media } \\
\text { yang sangat baik untuk melengkapi } \\
\text { pembelajaran tatap muka di kelas }\end{array}$ & 13,40 & 68,50 & 1,70 & 15,10 & 1,30 \\
\hline
\end{tabular}

Keterangan : SS - Sangat Setuju, S - Setuju, N-Netral, KS - Kurang Setuju, TS - Tidak Setuju

Ada banyak bukti literatur penelitian yang mendukung keunggulan lingkungan pembelajaran secara online. Kendall (2001) menyimpulkan bahwa pembelajaran online dapat mencapai tujuan pembelajaran dan kepuasan peserta didik. Sedangkan Ryan (2013) menyatakan bahwa diskusi online telah direkomendasikan sebagai media yang sangat efektif untuk membangun interaksi antar peserta didik sekaligus membangun refleksi aktif terhadap pengetahuan. Melalui forum online membantu peserta didik untuk mendapatkan pemahaman yang lebih baik tentang isi konten yang sedang dipelajari.

Aktivitas belajar secara online seperti forum online, chat, assignments, dan quiz membantu mahasiswa mendalami isi materi pembelajaran. Dari Tabel 1 dapat dijelaskan bahwa $83,20 \%$ ( $S=60,80 \%$; $S S=22,40 \%$ ) mahasiswa memberikan tanggapan positif terhadap pernyataan bahwa aktivitas seperti : forum online, chat, assignments, dan quiz membantu mahasiswa dalam mendalami isi materi. Melalui media online, dosen dapat dengan mudah membagi/mendistribusikan referensi/materi pembelajaran. Hal tersebut memudahkan mahasiswa dalam mendalami isi materi yang sedang dipelajari melalui sumber referensi yang relevan dan kredibel.

Pembelajaran online dapat membantu mahasiswa mendalami materi pembelajaran dengan lebih baik. Dalam kelas tatap muka 
mereka mempelajari konten pembelajaran secara tatap muka dengan dosen dan rekanrekan mereka, melakukan presentasi, dan diskusi. Sementara itu, di luar kelas mereka mendapat tambahan aktivitas secara online seperti diskusi online, membaca referensi, mengerjakan quiz dan kegiatan lainnya.

Saat ini, konsep pembelajaran telah berubah dari tradisional offline saja menuju blended-learning (menggabungkan antara kelas offline dan online). Blended-learning memiliki banyak keuntungan, diantaranya: kekayaan akan desain instruksional, akses yang mudah terhadap konten pembelajaran, interaksi sosial yang efektif, kemandirian belajar dan kemudahan dalam akses materi (Osguthorpe dan Graham, 2003). Hasil penelitian ini telah berhasil mengidetifikasi keuntungan dari blanded-learning (offline-online) yaitu : (1) membangun kemandirian belajar. Berdasarkan hasil angket, 91,80\% ( $S=66,80 ; \quad S S=25,00)$ mahasiswa memberi tanggapan positif (setuju dan sangat setuju) terhadap pernyataan bahwa menggunakan pembelajaran online (dalam model blended-learning) membantu saya/mahasiswa dalam mengembangkan kemandirian belajar.

Selain keuntungan-keuntungan yang telah disebutkan, ada keuntungan lain dari penerapan model blended-learning, yaitu: (1) pada saat aktivitas belajar secara online, memberi kemudahan mahasiswa dan dosen untuk melakukan aktivitas belajar dimana saja, kapan saja, tanpa dibatasi ruang dan waktu; dan (2) memberi kesempatan bagi mahasiswa untuk melakukan komunikasi tertulis.

Tidak dapat dipungkiri bahwa setiap individu memiliki cara (gaya) belajar yang berbeda. Dalam satu kelas, ada mahasiswa dengan mudah menyampaikan gagasan di dapan kelas. Namun, ada pula yang kurang mampu dalam menyampaikan ide/gagasan yang mereka miliki di dapan kelas secara lisan. Berdasarkan hasil penelitian, 69,40\% ( $\mathrm{S}=49,60$; $\mathrm{SS}=19,80)$ mahasiswa memberi tanggapan positif (setuju dan sangat setuju) terhadap pernyataan bahwa dengan aktifitas diskusi secara online, saya (mahasiswa) dapat menyampaikan pendapat dengan lebih baik dibandingkan ketika diskusi tatap muka di kelas. Dengan kata lain, ada lebih dari $1 \frac{1}{2}$ jumlah mahasiswa dalam satu kelas lebih mampu mengungkapkan ide-idenya secara tertulis. Adanya media online ini memberi kesempatan kepada mahasiswa untuk dapat menyampaikan ide-ide mereka secara tertulis.

Kesulitan pembelajaran tatap muka di kelas yaitu memberikan umpan balik berupa koreksi di setiap tugas mahasiswa. Umpan balik yang dapat diberikan dalam pembelajaran tatap muka sering bersifat umum saja, sehingga dosen kesulitan dalam mengamati perkembangan setiap individu tentang peningkatan tugas-tugas belajarnya. Hal tersebut dikarenakan waktu tatap muka yang begitu singkat, tidak memungkinkan memberi umpan balik satu per satu. Dengan adanya pembelajaran secara online, umpan balik menjadi lebih efektif. Hasil angket, 92,70\% ( $\mathrm{S}=56,90 \%$;SS=35,80\%) mahasiswa memberikan tanggapan positif (setuju dan sangat setuju) terhadap pernyataan bahwa tugas-tugas yang saya/mahasiswa kirimkan secara online mendapat koreksi dari dosen dengan cepat, sehingga saya dapat merevisi tugas.

Pembelajaran online dapat memberikan umpan balik baik setiap tugas mahasiswa dimana saja, maupun kapan saja tanpa dibatasi ruang dan waktu. Selain itu, mahasiswa mendapatkan notifikasi/ pemberitahuan secara online pada saat itu juga, karena aplikasi pembelajaran online dapat diakses melalui handphone yang sehari-hari mereka gunakan.

Menariknya, pembelajaran online ini memungkinkan dosen dapat dengan mudah memantau revisi setiap tugas mahasiswa yang telah dikoreksi. Dosen dapat memberi nilai (grade) pada setiap tugas yang dikirim oleh mahasiswa secara online, dan grade tersebut dapat dilihat oleh mahasiswa yang bersangkutan di layar hand-phone mereka. Mahasiswa dapat menanyakan tentang nilai, mengapa nilai mereka kurang? Apakah ada cara 
untuk perbaikan? Dalam pembelajaran online mahasiswa dapat melalukan remedi nilai tanpa harus menunggu waktu ujian. Dengan melihat masing-masing nilai pada setiap tugas, mahasiswa dapat melakukan remidi di setiap tugas yang nilainya masih kurang/rendah.

Pembelajaran online merupakan media belajar yang sangat baik untuk melengkapi pembelajaran tatap muka. Berdasarkan hasil angket, 81,90\% ( $\mathrm{S}=68,50 \%$; $\mathrm{SS}=13,40 \%$ ) mahasiswa memberikan tanggapan positif (setuju \& sangat setuju) terhadap pernyataan bahwa pembelajaran online adalah media yang sangat baik melengkapi pembelajaran tatap muka. Dengan demikian, media online dipadukan dengan kelas tatap muka dapat menjadi solusi atas permasalahan yang telah diuraikan sebelumnya.

Pembelajaran perlu dirancang dengan baik untuk memastikan bahwa mahasiswa mendapat pengalaman belajar yang cukup sesuai yang telah ditetapkan dalam SKS. Seorang dosen tidak hanya mengandalkan pertemuan tatap muka saja, namun harus memanfaatkan teknologi informasi untuk mencukupi kebutuhan belajar mahasiswa. Terdapat hal yang sangat penting untuk dipenuhi agar pembelajaran online dapat berhasil dengan baik. Untuk menjamin keberhasilan penyelenggaraan pembelajaran online perlu adanya tutorial. Kebingungan mahasiswa pada pembelajaran online harus dihilangkan yaitu dengan cara menyediakan tutorial yang mudah dipahami oleh mereka. Pengembangan tutorial menjadi penting di sini, sehingga tutorial harus dikembangkan secara sistematis dan teruji (Sukardi dan Rozi, 2018).

Merujuk Tabel 1, ada kecenderungan mahasiswa memberikan tanggapan negatif (KS,TS), meskipun kecenderungan tersebut tidak lebih besar persentasenya dari jumlah mahasiswa yang memberikan tanggapan $\mathrm{S}$ dan SS. Hal ini perlu penelitian lebih lanjut. Studi kualitatif mungkin diperlukan untuk mengungkap faktor yang mempengaruhi mahasiswa memberikan tanggapan negatif.
Menurut Ryan (2013), dosen tidak pernah bisa memuaskan semua mahasiswa mereka. Akan selalu ada yang merasa tidak senang dengan metode pembelajaran yang digunakan. Hal tersebut karena setiap individu memiliki cara belajar yang berbeda. Meskipun demikian, seorang pendidik tidak boleh berkecil hati, karena pembelajaran online telah terbukti menjadi alat pedagogis yang sangat efektif di semua tingkat pendidikan.

\section{Pengaruh Persepsi Mahasiswa Pada Pembelajaran Online Terhadap Pencapaian Hasil Belajar Teori Kejuruan. Hasil analisis data penelitian disajikan dalam Tabel 2. Uji Kendall's tau diperoleh Sig. (2-tailed) $=0,06>$ 0,05 , disimpulkan bahwa tidak terdapat pengaruh signifikan persepsi mahasiswa pada lingkungan belajar online terhadap pencapaian hasil belajar.}

Tabel 2. Hasil Uji Kendall's tau

\begin{tabular}{llll}
\hline & HB & $\mathrm{P}$ \\
\hline \multirow{3}{*}{ HB } & Correlation Coefficient & 1.00 & .13 \\
& Sig. (2-tailed) & & .06 \\
& $N$ & 117 & 117 \\
& Correlation Coefficient & .13 & 1.00 \\
$\mathrm{P}$ & Sig. (2-tailed) & .06 & \\
& $N$ & 117 & 117 \\
\hline
\end{tabular}

Ket. $\mathrm{HB}=$ Hasil Belajar, $\mathrm{P}=$ Persepsi

Seperti yang ditunjukkan pada Tabel 2 memberikan bukti empirik bahwa persepsi mahasiswa pada lingkungan belajar online tidak memiliki pengaruh yang signifikan terhadap hasil belajar. Temuan ini berbeda dengan penelitian lain. Misalnya Kauffman (2015), menyatakan bahwa persepsi negatif dapat menyebabkan hasil belajar yang tidak menguntungkan, menurunkan motivasi, dan ketekunan.

Hasil penelitian ini memberi wawasan bahwa mahasiswa dapat belajar dengan baik pada pembelajaran online dan pembelajaran tatap muka di kelas terlepas dari persepsi yang mereka miliki. Berdasarkan Tabel 2, koefisien $r=0,13$. Koefisien determinasi $0,13^{2}=0,017$. Dengan demikian, besarnya nilai kontribusi 
persepsi terhadap hasil belajar hanya $1,70 \%$. Dengan kata lain, $98,30 \%$ hasil belajar ditentukan oleh faktor lain.

Terdapat beberapa faktor yang dapat mempengaruhi hasil belajar, misalnya : IQ (Intelligence Quotient) atau kecerdasan diri. Individu yang memiliki persepsi yang baik pada lingkungan belajar, namun memiliki IQ sedikit rendah, bisa saja gagal mencapai hasil belajar yang memuaskan. Sayangnya, penelitian ini tidak mengukur variabel IQ. Penelitian masa depan perlu menyelidiki hubungan antara persepsi diri, IQ, dan hasil belajar. Selain itu, dalam pembelajaran online mungkin tidak sesuai untuk sebagian gaya belajar mahasiswa. Faktor tambahan yang dapat mempengaruhi persepsi mahasiswa perlu diselidiki, seperti gaya belajar dan sikap individu terhadap lingkungan belajar online.

\section{SIMPULAN}

Pada akhirnya, penelitian ini memberi simpulan bahwa pembelajaran online (plat form Moodle) merupakan media belajar yg sangat baik untuk melengkapi pembelajaran tatap muka di kelas. Meskipun hasil uji statistik Kendall's tau memberi kesimpulan bahwa persepsi tidak memberikan pengaruh signifikan terhadap hasil belajar. Namun, penelitian ini memberikan wawasan bahwa mahasiswa dapat belajar dengan baik pada pembelajaran online dan pembelajaran tatap muka terlepas dari persepsi yang mereka miliki.

Calon lulusan Perguruan Tinggi harus disiapkan dengan baik untuk memenuhi tantangan Industri 4.0. Salah satu caranya dengan memberi pengalaman belajar, bukan hanya di dalam kelas tatap muka saja, tapi lebih dari itu. Pembelajaran saat ini dituntut untuk tidak hanya fokus tatap muka saja, namun dituntut untuk lebih memanfaatkan teknologi.

\section{DAFTAR RUJUKAN}

Endrotomo. 2016. SKS : Pemikiran Perhitungan Jumlah SKS Program Pendidikan dan Besaran SKS Mata Kuliah, Article.

Kendall, M. 2001. Teaching Online to Campusbased Students: The Experience of Using WebCT for the Community Information Module at Manchester Metropolitan University. Education for Information, 19(4), pp. 325-346

Kauffman, H. 2015. A review of Predictive Factors of Student Success in and satIsfaction with Online Learning. Research in Learning Technology, Vol. 23.

Osguthorpe \& Charles R.G. 2003. Blended Learning Environments Definitions and Directions Russell T. Article.

Ryan, R.S. 2013. The Effect of Online Discussion Forums on Student Learning and Student Perception of Learning in a Science Course at the Community College Level, Dissertations, University of Southern Mississippi.

SN-Dikti. 2015. Peraturan Menteri Riset, Teknologi, dan Pendidikan Tinggi.

Sukardi \& Rozi. 2018. Pengembangan Tutorial Pembelajaran Online Moodle Untuk Meningkatkan Efektivitas Perkuliahan. Laporan Akhir Penelitian Dosen Pemula.

Tayebinik, M, \& Puteh, M. 2013. Blended Learning or E-learning?, Article

Tuncay, N, Uzunboylu, H \& Teker, N. 2011. Students Evaluation of Edu 2.0: a Case Study. Journal of Procedia - Social and Behavioral Sciences, (28), 948 - 956. 